\title{
A HISTORY OF THE TASMANIAN SCALLOP INDUSTRY: DIAGNOSING PROBLEMS OF MANAGEMENT
}

\author{
by R.A. Perrin and P.R. Hay
}

(with one table)

PERRIN, R.A. \& HAY, P.R., 1987 (30:vi): A history of the Tasmanian scallop industry: diagnosing problems of management. Pap. Proc. R. Soc. Tasm., 121: 1-14. https://doi.org/10.26749/rstpp.121.1 ISSN 0080-4703. Centre for Environmental Studies, University of Tasmania, Hobart, Australia 7000.

Three distinct phases occur in the history of management of the Tasmanian scallop industry, corresponding with a shift in the industry's locus, from D'Entrecasteaux Channel to the East Coast, and thence to Bass Strait. Each shift was prompted by crisis in the industry, and though the result on each occasion was to dramatically increase the scale of the industry, the record has been one of ad hoc implementation of ultimately ineffective strategies. Though there are some local factors accounting for this, most are deep-seated and resistant to easy resolution - they have to do with the biology of the scallop, with its status as a common property resource, and with the ongoing failure to develop theoretical models of fisheries management appropriate to the scallop industry. It seems unlikely that the industry's management problems can be easily and quickly solved.

Key Words: scallop industry, Tasmania, management.

\section{INTRODUCTION}

Beginning as a weekend leisure activity for a few enterprising Hobart citizens at the turn of the century, scallop fishing has developed into a major, highly-capitalised industry. It is an industry which has been the subject of many controversies in its comparatively short history, and these have both stemmed from and been fueled by periodic collapses of production in the industry. That these collapses continue to occur suggests one or both of the following: a poor management record and/or chronic problems stemming from the biological and resource nature of the scallop. We believe the latter to be more significant. Though some lack of political will to come to terms with the problems is evident, the obstacles to sound management are nevertheless formidable, and defy easy resolution. It is thus unreasonable to expect too much progress too soon.

ln the account which follows, three distinct periods are identified, each corresponding with industry expansion as focus shifted from depleted to major new beds.

\section{TO 1950'S: INDUSTRY BASED ON THE D'ENTRECASTEAUX CHANNEL}

Europeans did not exploit scallops in a significant way until the early 1900 's. A Royal Commission into the fisheries of Tasmania in 1883 deemed the only shellfish worthy of special notice to be oysters and mussels (Seal et al. 1883). The Commission noted the consumption of scallops in the vicinity of the coast, but reported that scallops did not find their way to the Hobart market. One petitioner to the Commission stated that only oysters seemed to be considered of value and in demand and that the poor of Tasmania did not avail themselves of the possibilities of employment in an industry which in England and elsewhere provided employment for thousands. There was evidence even at this stage of over-exploitation of fishing resources, for oysters, once plentiful around the coastline, now existed in commercial quantities only in the vicinity of Spring Bay (loc. cit.). The need for management of the ocean fisheries was clearly recognised, and the Commissioners saw historical developments in other fishing industries, and research into the natural history of fish species as two important considerations in the formulation of a fisheries management policy.

Until this time, Tasmania's fisheries had been managed by the Salmon Commissioners (see table 1), appointed in 1861 (Henry 1861), and mostly involved with the stocking of Tasmanian rivers with salmon or trout via the importation and breeding of salmon and trout eggs (Innes 1865). In 1884 however, in response to the 1883 Royal Commission findings, $\mathrm{Mr}$ W. Saville-Kent was 
appointed Superintendent and Inspector of a newly created Fisheries Department (table 1). Although Saville-Kent (1886) was concerned mostly with the problems of the oyster fishery he did comment on the general state of the Tasmanian sea fisheries and suggested that investment in the fishing industry would be worthwhile with "the adoption of newer methods and a more extended and systematic plan of working the fisheries and disposing of their produce." Thus even at this time there was an awareness of the need for management in the development of the fishing industry.

Although no significant market existed for scallops in the nineteenth century, in the early parts of the twentieth century scalloping was undertaken from rowing or sailing boats and by using small dredges in the vicinity of the Marine Board Shipyards and Rose Bay (Fairbridge 1953) and as far north as New Town Bay (E. Guiler, pers. comm.). Both the commercial scallop Pecten fumata Tate and the doughboy scallop Chlamys asperrimus Lamarck were being caught. It seems that the only other species of scallop found in Tasmania, the queen scallop Equichlamys bifrons Lamarck was less common than the other two species, and was not mentioned in the earlier reports referred to above. By 1905 internal combustion marine engines had been introduced and the major technological impediment to full-scale exploitation of the scallop resource was removed. Though existing scallop beds around Hobart had begun to dwindle, dredging could now move to the entrance of the Derwent River, Ralphs Bay and the Channel. The young ind ustry was quite buoyant and sufficient quantities were being taken to satisfy demand, mostly from hotels which provided free scallop counter lunches.

Until 1893 the Commissioners of Fisheries were supported by an annual parliamentary vote, but after that year they derived their salaries and running costs from the taking of fees levied on fishermen (Seager 1908). Apparent over-exploitation of the known scallop beds was already taking place. The decline in the number of scallops in the vicinity of Hobart led the Commissioner of Fisheries, Mr P. Seager, to impose in 1908 the first closure, when scalloping in the Derwent was discontinued "to allow the beds to recuperate"(Seager 1908). The Commissioner was petitioned by the scallop fishermen on more than one occasion to re-open the scallop beds; instead he appointed a two-man committee to test the recovery or otherwise of the bed (Seager 1910). The committee made eleven dredge hauls over the Derwent River beds and found virtually no young scallops growing on the western side of the Derwent, though there was a reasonable growth elsewhere. Factors thought to be contributing to the poor growth of scallops were an increase in the number of Auricula sp. (a parasitic protozoan), the increasing silt load in the river, the discharge of sewage and an increase in algal growth. The committee recommended the reopening of the beds to scalloping on the grounds "that a thorough cleaning of these beds might effect an improvement" (The Mercury 8 July 1910). The Commissioner of Fisheries demurred - he did not consider the committee's findings justified its conclusions and he declined to remove the restrictions, but the committee was authorised to make further investigations (Seager 1910). In 1912 it was decided on the recommendation of the committee to reopen the Derwent to scalloping, with the following restrictions; that scallops could be taken by dredges towed by boats propelled by oars only, and the person taking the scallops was to pay a licence fee of five shillings for each dredge used (Seager 1912). When these restrictions were lifted is unclear.

The scallop fishery was not mentioned in a second Royal Commission on Tasmanian Fisheries in 1916 , indicating that the fishery was still operating only on a small scale. The Royal Commission inquired into the causes of the high price of fish on the local market and was critical of the way most fisheries were unexploited in Tasmania, stating that "no island state has ever yet reached full development without the thorough exploitation of its fishing resources"(Flynn 1916), an assessment hardly justified in the case of scallops which by this time had all but disappeared from the major field - the Hobart area of the Derwent. In 1918 the Commissioner of Fisheries appointed a further committee, headed by T. Thompson Flynn, Ralston Professor of Biology at the University of Tasmania, to continue investigations into the reduction in scallop numbers in the Derwent River. Intensive dred ging over the scallop beds, produced "as many full-sized scallops as could be counted on the fingers of both hands"(Flynn 1918). In Flynn's first report he suggested four possible causes of the decline in the scallop population: increased silt and mud load in the river, increased numbers of parasites, increased numbers of starfish, and fluctuations in the water salinity. In his second and final report he found that the Derwent was again stocked with young scallops and concluded that their previous disappearance had been caused by unusual flooding, resulting in an increase in silt load in the Derwent and drastic fluctuation in the water salinity (Flynn 1919).

The Commissioner of Fisheries' report for the year 1918-19 stated that "the industry of 
TABLE 1

Evolution of Tasmanian fisheries management structure.

\begin{tabular}{|c|c|c|c|}
\hline Management Authority & Year & Legislation & Comments \\
\hline $\begin{array}{l}\text { Salmon and Freshwater } \\
\text { Fisheries Commission }\end{array}$ & 1861 & $\begin{array}{l}\text { Government Notice } 148 \\
-21 \text { October } 1861\end{array}$ & $\begin{array}{l}\text { A } 6 \text { member commission set up to oversee the } \\
\text { importation of salmon ova from England. }\end{array}$ \\
\hline $\begin{array}{l}\text { Superintendent and } \\
\text { Inspector of Fisheries* }\end{array}$ & 1884 & Fisheries & $\begin{array}{l}\text { Mr W. Saville-Kent was appointed as a result } \\
\text { of the } 1882 \text { Royal Commission on the Fisheries } \\
\text { of Tasmania. }\end{array}$ \\
\hline Fisheries Board & 1887 & $\begin{array}{l}\text { Government Notice } 321 \\
-8 \text { November } 1887\end{array}$ & $\begin{array}{l}\text { A } 23 \text { member Board appointed partly as a } \\
\text { result of } \mathrm{Mr} \text { Saville-Kent's recommendation. }\end{array}$ \\
\hline $\begin{array}{l}\text { Commissioners of } \\
\text { Fisheries }\end{array}$ & 1889 & Fisheries Act, 1889 & $\begin{array}{l}25 \text { people were appointed as Commissioners of } \\
\text { Fisheries on } 16 \text { December, } 1889 .\end{array}$ \\
\hline Sea Fisheries Board & 1925 & Fisheries Act, 1925 & $\begin{array}{l}\text { The Commissioners of Fisheries were split, in } \\
\text { 1925, into the Salmon and Freshwater Fisheries } \\
\text { Commission and the Sea Fisheries Board which } \\
\text { comprised } 4 \text { members. }\end{array}$ \\
\hline $\begin{array}{l}\text { Fisheries Division, } \\
\text { Department of Agriculture }\end{array}$ & 1941 & Fisheries Act, 1935 & $\begin{array}{l}\text { The Division was supervised by the Department } \\
\text { of Agriculture and headed by Mr R. Scott. }\end{array}$ \\
\hline $\begin{array}{l}\text { Fisheries Division, } \\
\text { Department of Agriculture } \\
\text { and the Tasmanian } \\
\text { Fisheries Development } \\
\text { Authority (T.F.D.A.) }\end{array}$ & 1977 & $\begin{array}{l}\text { Fisheries Development } \\
\text { Act, } 1977\end{array}$ & $\begin{array}{l}\text { The T.F.D.A. was established on the } \\
\text { recommendation of the O'Kelly Report, } \\
\text { commissioned in } 1976 \text {. }\end{array}$ \\
\hline $\begin{array}{l}\text { Department of Sea } \\
\text { Fisheries }\end{array}$ & 1985 & $\begin{array}{l}\text { Fisheries Development } \\
\text { Repeal Act, } 1985 \\
\text { Fisheries Amendment } \\
\text { Act, } 1985\end{array}$ & $\begin{array}{l}\text { A second review by O'Kelly in } 1984 \\
\text { recommended the disbanding of the T.F.D.A. } \\
\text { and reforming a Sea Fisheries Department. }\end{array}$ \\
\hline
\end{tabular}

* From 1884-1941 the management authority was known as the "Fisheries Department"an appellation which disguises the significant changes (including nomenclature changes) outlined above.

scalloping has now assumed such importance to the people that it must be developed and protected" (Seager 1919). Despite this recognition however, no new management initiatives seem to have been set in place. Again the focus of scalloping began to shift, from Ralphs Bay and the mouth of the Derwent, to the northern half of D'Entrecasteaux Channel. The industry expanded slowly. In 1920 only two scallop boats were engaged full-time in the trade; in 1924 several boats were scalloping. The increased pressure on the scallop stocks resulted in a number of management decisions aimed at protecting the stock. A season of six months, from April to September, and minimum sizes of three and a half inches $(85 \mathrm{~mm})$ for the commercial scallop and two and a half inches $(63.5 \mathrm{~mm})$ for the doughboy scallop, were imposed (Brown 1960). This virtually ended scalloping in the Derwent River and Ralphs Bay and increased the effort in the northern parts of D'Entrecasteaux Channel and in Northwest Bay.

In 1925 the government replaced the Commissioner of Fisheries with the four member Sea Fisheries Board (table 1) with the professed aim of stimulating development in marine fishing (Ogilvie 1925). One of its first acts was to close the northern beds of the D'Entrecasteaux Channel, apparently to prevent over-fishing (Fairbridge 1953, Brown 1960). It is hard to assess the accuracy of the overfishing claim at this time as there were no annual reports to parliament by the Sea Fisheries Board from 1925 until 1941; available data consist only of the 1929 to 1939 total scallop catch figures, which were collected verbally by the Inspector of Fisheries. These demonstrated the comparatively small scale of the industry at the beginning of this period, though steady and impressive growth occurred after 1933 (Harrison 1965). The species-basis of the 
industry was also changing. Until 1932 larger numbers of commercial scallops were taken; after this time doughboy scallops were taken in greater numbers. Harrison 1965) suggested that the manifest economic advantages of commercial over doughboy scallops can only mean that the commercial scallop was quite rare in the D'Entrecasteaux Channel during the 1930's.

As well as closure in 1925 of the Channel for two years, other management measures were taken in the interests of conserving the resource. In 1928 the scallop season was reduced by two months, whilst the Channel beds were re-opened for fishing, only to be closed again in 1930 and 1931. The minimum legal size of the commercial scallop was changed by the Sea Fisheries Board in 1934 from three and a half inches $(85 \mathrm{~mm})$ at its largest diameter to three and a half inches at its smallest diameter. In 1935 dredges were limited to a width of four feet $(1.2 \mathrm{~m})$ to protect the scallops from being crushed by the weight of the net being dragged over the bottom. From 1938 until 1942 there were fluctuations in the total catch of scallops due to petrol and manpower shortages during World War II: however meat rationing increased the demand for scallops and resulted in stepped-up fishing effort, facilitated by the extension of the scallop season by two weeks.

An important change in ind ustry management at this time was the transfer, in June 1941, of the functions and responsibilities of the Sea Fisheries Board to the Minister for Agriculture (table 1). An Advisory Board was constituted, consisting of the Secretary for Agriculture, Secretary of the Police Department, a zoologist, a fish processor, and two fishermen representing the south and east coasts (Smith 1942). Annual reports of the Board were published as part of the Agriculture Department's reports.

The Channel scallop industry continued to increase production through the 1940's, but in 1949 catches decreased markedly, indicating that almost fifty years into its history, little progress had been made in effective regulation of the resource. From the foregoing it will be apparent that little consistency or sophistication characterised attempts to manage the resource in this early phase. Though the means adopted - restrictions on permissible technique, limitations, via licence, on open access to the resource, and temporary bed closure remain the major regulatory tools to the present, little progress was made toward understanding the nature of the resource or monitoring population changes. Assessment was not continuous but occurred only when serious drops in the scallop population had become obvious. Subsequent restrictions were thus never in time to protect the industry in the short term, though sufficient to permit recovery in the intermediate term.

\section{0'S-1973: INDUSTRY BASED ON THE EAST COAST BEDS}

The poor catches of the late 1940's continued into the early 1950's. A.M. Olsen, Senior Research Officer with the CSIRO Division of Fisheries, carried out research in the 1950's aimed at explaining the decline in Channel scallop numbers. He found the minimum concentration of scallops for economic fishing to be two per square yard (approx. one square metre) and established that the scallops were preyed upon by the large whelk or band shell Fasciolaria australasia Perry and by the elevenarmed starfish Coscinasterias calamaria Gray. Olsen (1955) contended that concern expressed about the reduction in scallop numbers in the D'Entrecasteaux Channel may have been misguided:

It is well recognized that fishing never exterminates a stock but reduces the stock to individuals of minimum legal size and/or an uneconomic level of operation. Therefore so long as there is an a mple breeding stock of those below the minimum legal size, any proposal restricting areas of dredging is preventing the rational exploitation of a fishable stock.

Olsen's controversial position set one of the boundaries to the appropriate management response to population shortfall debate which continues to this day.

Despite the attention still being accorded the Channel, it was shortly to be eclipsed as Tasmania's prime bed. Increasingly the industry began to explore and exploit beds on the east coast of Tasmania, and the late 1950's was a period of industry expansion.

In 1960 a Select Committee of the Legislative Council was appointed to inquire into the scallop fishery. The enquiry was initiated by the controversy surrounding the introduction of a new spiketoothed dredge, the "sputnik" dredge. Apparent damage to the scallop beds prompted submissions from 45 fishermen, an indication of considerable concern. Other issues raised by the fishermen included perceived inadequate management by the Fisheries Division, and in particular the lack of research into scallop behaviour and that of its major predator, the starfish (Prince et al. 1960). This constitutes the first clear evidence of a rift between regulator and client. It reflects the inherent 
and persistent difficulties of scallop management alluded to earlier: one would expect these to lead to friction and impatience between industry and management, and the wonder of it rather is that clear evidence of this dissatisfaction has not been found in earlier periods. It may also be a measure of the greatly increased professionalisation and technological sophistication of the industry from the 1950's.

The select Committee brought down an Interim Report which made a number of management recommendations. Many of these aimed at overcoming research and monitoring deficiencies characteristic of the industry hitherto. These included the appointment, for the first time, of research staff specifically to investigate scallops (or, more accurately, to give scallop research priority amongst other research tasks), and investigation of the scallop beds. Nevertheless, most recommendations involved expansion and sophistication of existing techniques aimed at guaranteeing the resource against over-exploitation: increasing the number of fisheries inspectors, increasing fines for breaches of fisheries regulations, registering sheds where scallops were split, shortening the scallop season by two weeks, prohibiting night fishing, restricting the issue of scallop licenses, reintroducing separate licences for scallop fishing (including special endorsements for the Channel area and Norfolk Bay beds), taking a substantial fee to provide a worthwhile contribution to the administration of the Sea Fisheries Board, and undertaking a program to control starfish numbers (Brown 1960). The emphasis in the above recommendations on tightening the Board's policing effectiveness highlights the Select Committee's belief that a major reason for earlier management failure was incapacity to enforce adequately the measures taken, rather than inappropriateness of the measures themselves.

After research into the effects of different types of dredges on scallop beds the Committee submitted a second report in 1961 which recommended that the lip dredge and lip dredge with runners be permitted; that restrictions on dredge type only apply to the D'Entrecasteaux Channel; that a fisherman education program begin; and that Tasmanian scallop processors market their scallops so that they be clearly and attractively identified as Tasmanian (Brown 1961). Little good seems to have come from these recommendations; the lip dredge with runners proved unsuccessful, no effective program aimed at fisherman education was set up, and there was no apparent increase in marketing Tasmanian scallops as Tasmanian.
The success of the more important recommendations in the Interim Report was also mixed. Research into scallop dredge design was undertaken, night fishing was prohibited in the Channel, a temporary reduction of the season was instituted, and scallop sheds were registered with the Department of Health. Other recommendations were either not adopted or proved ineffective. For instance, there was no restriction on the issue of scallop licences, and no substantial fee was taken to contribute to the administration of the Board, whilst an increase in fines for breaches of fisheries regulations was instituted, but to no good effect, as magistrates tended habitually to impose only the minimum fine.

The disappointing fate of the Select Committee's recommendations reflects the management difficulties posed by scallop utilization, and the mix of incapacity and unwillingness to tackle with determination these difficulties on the part of management. It lends credence to the feelings of some fishermen that the government lacked the will to apply the recommendations stem ming from the Select Committee enquiry. The Channel scallop beds were partly closed again in 1964 as a result of over-fishing, and incentives were thereafter given to fishermen by the Sea Fisheries Advisory Board to locate new scallop beds to maintain the fishery. The incentives took the form of temporary exclusive rights of access to a newly discovered scallop bed. By the late 1960's the east coast beds were also becoming severely depleted, further highlighting the failure of the State's management strategy. The late 1960 's were years of low spatfall, and at this time Tasmania had to confront serious interstate competition for the first time. Although Victoria's scallop industry only came into being in the early 1960's (as a result of exploration by Tasmanian fishermen), by 1970 it had supplanted Tasmania as Australia's leading scallop producer (Sanders 1970). The constitutional problems the industry experiences today date from this time.

Yet again the industry was in a state of crisis, and in danger of collapsing under the twin weights of years of poor recruitment and vigorous interstate competition. Again crisis forced the ind ustry into a new phase, as management responded in the same way as it had done in the 1950's; it launched a campaign to discover exploitable new beds. Much of the initiative to find new scallop beds was undertaken by the Sea Fisheries Division of the Department of Agriculture, which surveyed 800 square miles (approx. 200,000 hectares) of Bass Strait for scallop beds in 1972 . This search revealed four areas with high densities. The depletion of the 
scallop stocks in the Derwent River and Ralphs Bay, the Channel and finally the east coast led the Minister for Agriculture, Mr L. Costello, to release policy statement regarding the likely exploitation of the Bass Strait scallop beds. According to $\mathrm{Mr}$ Costello "a slower rate of exploitation by smaller, lighter dredges was considered to be more desirable than an uncontrolled quick decimation of the stock" (The Mercury 6 June 1973). A determination not to re-commit the errors of the past seemed evident. Nevertheless, occasionally remnants of old ways of thinking remained in evidence, such as $\mathrm{Mr}$ Costello's threat on 13 June 1973 that unless local interest in the newly opened Bass Strait beds quickened, he would throw those beds open to Victorian fishermen, as "he was not prepared to see a valuable food resource 'wasted'" (The Mercury 14 June 1973). Such a statement reads almost incredibly in light of current interstate tension over exploitation of what has, in turn, proven a finite fishing resource, and leads one to question how deeply embedded, in 1973, was the apparent newfound determination to husband the resource wisely and to adopt a more responsible approach to management.

\section{3-PRESENT: INDUSTRY BASED ON BASS STRAIT BEDS}

This period has seen not only a shift in the geographical locus of the industry - it is also characterized by a greatly stepped-up research emphasis, at least by comparison with the industry's earlier phases. Since 1973, for instance, the Sea Fisheries Division of the Department of Agriculture has been conducting biological studies into the life history of the scallop with the aim of assessing the potential for scallop aquaculture, which would involve the growing of young scallops artificially and then releasing them into depleted natural areas (Dix 1975).

In 1976 the Tasmanian government commissioned a report on the fishing industry by the Chairman of the Irish Sea Fisheries Board, $\mathrm{Mr}$ B. H. O'Kelly. That report found that further development was hindered by the "existing administrative structure", in that the Fisheries Division, a small group within the Department of Agriculture, could not manage effectively because of the need to live with wider departmental priorities, and other problems relating to the inertia and unwieldiness often characteristic of large bureaucracies. O'Kelly recommended the establishment of a Sea Fisheries Development Authority charged with specific responsibility for the development of the industry.
The government endorsed the report and established the Authority under the Fisheries Development Act which came into effect in September 1977 (table 1). Though the Sea Fisheries Division remained, the Tasmanian Fisheries Development Authority (TFDA), consisting of a chairman (the manager of the Agricultural Bank of Tasmania) and four other government appointees, commenced operation later that year, with three aims: to promote and develop the fishing industry; to maintain standards of exports and local products; and to research the management of living resources (Shoobridge 1979). One of the Authority's first acts was to expand the earlier work on scallop aquaculture.

Scallop fishing in Bass Strait introduced a new set of management problems. Questions of Federal-State jurisdiction over coastal waters became apparent in the 1970's and remained long unresolved. Until June 1986, Tasmanian authorities had control over the waters up to 3 nautical miles (approx. $5.6 \mathrm{~km}$ ) from the coastline, while the Federal authorities controlled the 3 to 200 nautical mile Exclusive Fishing Zone. This led to competition between Victorian and Tasmanian scallop boats with the potential result of over-fishing and economic hardship for some scallopers, and a possible spillover of excess fishermen into other fisheries such as the crayfish and shark fisheries. In 1979 Tasmanian fishermen took their concern to government and the then Minister for Sea Fisheries, Dr J. Amos, called for a division of Bass Strait along the $39^{\circ} 12^{\prime} \mathrm{S}$ parallel, a simple enough claim which gives no hint of the formidable constitutional and political difficulties standing in the way of such a course of action. Predictably, no action ensued at that time and subsequent slow progress toward reaching the Off-shore Constitutional Settlement highlights these difficulties. Lack of progress toward putting the Settlement in place was locally ascribed to intransigence on the part of the Victorian Government, which was reluctant to have its industry's access to Tasmanian waters removed, this being the effect of a related but separately wrought agreement whereby exclusive rights to fish to 20 nautical miles (approx. $37 \mathrm{~km}$ ) from the coast devolve to Tasmania.

The controversy surrounding the management of the scallop beds resulted, in November 1983, in a joint Commonwealth-Victorian-Tasmanian moratorium on the issue of scallop licences to fish in Bass Strait until the end of 1984 (the "interim Management Regime"), to give the Commonwealth time to evaluate a comprehensive long-term management plan for this area. The 
moratorium was designed to limit the entry of boats to the Bass Strait fishery as a means of controlling the build-up of fishing capacity. Eligibility for a licence was based on a demonstrated commitment to the fishery which could be shown in a number of ways, such as by proving that a boat had fished in the area during the previous season, by having commenced to build a boat for scalloping, or by holding a licence to fish for scallops in the coastal waters of Victoria. A second major intergovernmental initiative for the Bass Strait scallop fishery, the Bass Strait Scallop Fishery Task Force, consisting of officials from the Commonwealth, Tasmanian and Victorian fisheries authorities and from the industry, was established in June 1984 to prepare a report on options for future management of the fishery for consideration by the relevant governments. In July 1985 the relevant State and Commonwealth Ministers announced details of a new management regime, involving the phased handing over of responsibility for the fishery to Victoria and Tasmania (after each State had provided a management plan for its zone). This was enabled by the decision of the Commonwealth to implement the Fisheries component of the Offshore Constitutional Settlement, and means that the fishery can eventually be controlled under a single law. Under the scheme, three fisheries were created - one controlled by each of the States to 20 nautical miles offshore, and a third under joint Tasmanian-Victorian control. After much delay this came into effect in June 1986.

Of recent years there has been some recovery in Tasmania's depleted beds. The D'Entrecasteaux Channel scallop fishery was again opened, after 15 years closure, to commercial and amateur fishermen in 1982. Severe restrictions were imposed. Commercial scallops could not be taken at all after the 1983 season, bag limits were introduced, and the scalloping season was set at three weeks. There was, however, no restriction on the numbers of boats allowed to fish and in 1983, 666 recreational boats and 70 commercial boats were working the beds. In 1984 the daily bag limit for amateurs was reduced from one bag containing up to 1000 scallops to one bag containing 400 scallops and for professional fishermen from 15 bags containing a total of 15000 scallops to 20 bags containing a total of 8000 scallops.

Changes also continue to occur in the structure of industry management. In February 1985 the TFDA and Sea Fisheries Division became incorporated in the Department of Sea Fisheries (table 1) whilst the Fisheries inspectors were incorporated into the Police Force. There are also indications that the research effort of the last decade is starting to yield results. It was announced, for instance (The Mercury 25 January 1986), that the Department of Sea Fisheries had achieved a "major breakthrough" in the "re-establishment of over-fished scallop beds", involving "the transplanting of scallops from controlled breeding ground so the seabed", a process whereby scallops are able to reach legal size "in as little as 17 months" instead of the normal two to three years.

That management continued to find resolution of the industry's long-standing problems difficult however, is evinced by the media-grabbing turmoil which reigned in the industry through 1985. At one stage violent clashes between Victorian and Tasmanian fishermen seemed imminent, and there was talk of new beds being fished out within days of discovery, of excessive catches going to rot, of splits in the ranks of the Tasmanian Scallop Fishermen's Association, and a general increase in fishermen militancy. The Mercury was in no doubt about the continued failure of management to regulate the industry effectively. It editorialised (21 October 1985): "Every time a new bed is discovered, it is virtually fished to exhaustion as fishermen flock in to reap a benefit from a bonanza they know from past experience will have a limited life."

\section{LESSONS FROM HISTORY}

From a management perspective, the most striking aspect of this history is that, from its beginnings to the present, problems and management responses have remained little changed though considerable experimentation with administrative structures and arrangement has taken place. The ind ustry's major beds have been subject to spectacular and largely unpredicted falls in population, and no mechanisms has been found to control fishing effort in such a way as to stabilize the ind ustry both ecologically and economically. In the past crises have been averted by the discovery and opening up of new beds, but this option is probably no longer available in any major sense, whilst the increase in fishing capacity in the wake of significant technological innovations since the 1950 's now provides the means to overfish such new beds as are located in an extremely short period of time. Pressure on management has thus increased commensurate with fishing capacity.

It is beyond the scope of this paper to prescribe management solutions. This has become a major government priority, and it is also the focus of academic investigation elsewhere. We intend merely to account for the management record 
outlined above. Some of the difficulties can be attributed to inadequate resources and a lack of political will on the part of the authorities. Instances of this can be intelligently guessed at from the account given above. But it is also necessary to identify the chronic and possibly greater difficulties which are inherent in scallop management. To these we now turn

\section{FACTORS CONDUCIVE TO MANAGEMENT FAILURE}

\section{Scallop Biology}

The problems posed by the biological nature of the resource have been well identified elsewhere (Harrison 1965, 1975, St Leger 1964, Dix 1981, Hortle 1983) and will be only briefly surveyed here. They are, however, formidable. Harrison (1975) has noted the "apparent sensitivity of the recruitment process to environmental conditions", whereby "we have a population behaviour pattern perhaps more a kin to that of plague insects such as locusts than fish". Annual fluctuation in the spatfall success rate of all species of Tasmanian scallop is enormous. This is not peculiar to Tasmania - it has been reported from nearly all scallop fisheries, both in Australia and elsewhere. The causes of these fluctuations are still unknown, but their importance to the health of the fishery is undoubted. The number of larvae settling in one year will determine the availability of stock for the fishery in approximately three years time. Fishermen who exploit an area of scallop beds in one year are not necessarily guaranteed a sucessful consecutive year owing to this variability of spatfall. This factor may underlie the major collapses which have occurred in the scallop fishery since exploitation began. Thus an accurate assessment of the spatfall success is crucial to good management procedures. In addition, little is thus far known of the scallop's susceptibility to disease.

\section{The Failure of Theoretical Models}

As with other fishing industries, scallop management suffers from the failure to develop the appropriate theoretical models to obviate the necessity of reinventing the wheel every time a management strategy must be devised. There are three competing paradigms of fishery exploitation: Maximum Sustainable Yield (MSY), Maximum Economic Yield (MEY), and Optimum Sustainable Yield (OSY). We contend that all have proven of limited practical use.
The MSY concept has underwritten most fishing management policies in the past fifty years or so (Larkin 1977). It first arose as a management concept in the early twentieth century in the Norwegian whaling industry. Using information they had collected on fin and blue whales from the Antarctic and off the Icelandic coast, the Norwegians discussed the relationship between regeneration and catch of whales in the hope of finding a mathematical model to help them establish the minimum stock of whales which could yield a given catch without exterminating the stock. They found that in the case of whales the data base was not sufficient to afford an adequate foundation for a calculation: however they did suggest that there is a definite level to which the whale stock can be reduced, while preserving the maximum capacity of regeneration and at the same time securing an optimum catch. Others (Ricker 1948, 1958, Fry 1947, Schaefer 1954, Beverton \& Holt 1957) further refined the concept, and it became the standard strategy for fisheries management, in Australia, as elsewhere. Larkin (1977) provides a jaundiced definition: "any species each year produces a harvestable surplus, and if you take that much, and no more, you can go on getting it for ever and ever".

The theoretical validity of MSY has been demonstrated under laboratory conditions, but attempts to use MSY as the sole management tool in the field have met with severe problems, leading one fisheries scientist to state that "the generalised concept of MSY is elegant in both its simplicity and its adherence to the basic theories of the behaviour of the population. The problem is that as applied it is totally unsound." (Talbot 1978).

What then are the major problems confronting the fisheries manager who attempts to use MSY as the major management objective? The most fundamental problem is the difficulty of observing and accura tely measuring the relevant dynamics of any living marine resource. This is due in part to the technical problems of data collection in the marine environment but also to the heavy costs associated with sampling and processing data. The most extensive sampling programme of the fishing resource is undertaken by the fishermen themselves; however their figures are never completely free of reporting biases, for the fishermen have an economic disincentive to divulge such fishing catch data as locality and abundance of fish stocks for fear of advantaging their fishing competitors, whilst there is also in many cases a lack of scientific method and accuracy in recording results. In the Tasmanian scallop industry estimates of scallop numbers are made by making a number of dredge 
hauls over known scallop beds (Zacharin 1985). This system allows an estimate of the capabilities of the beds to support a fishery in any given year but because of the extremely variable recruitment of the scallop, it would only provide a tenuous basis for an MSY prediction.

A second problem concerns the failure of the MSY concept to deal with multispecies fisheries, as it was derived to predict the yield of one species or race only. For example, in the Pacific Northwest salmon fishery it has been found that the salmon population consists of races with different growth rates, recruitment, and mortality, and thus, different yield functions. They can however be caught together in the one net. An MSY estimate in this case ideally should be made for each race (Ricker 1973). The Tasmanian scallop fishery sometimes involves the dredging of more than one species of scallop as well as an assortment of other species of fish, invertebrates and algae. At present these other species have no commercial value (it is possible that some of them may eventully be utilized as food sources, or as fertilizer), though their value to the marine ecosystem, as yet unknown, could be considerable. The harvesting of trophically linked species can also drastically reduce the MSY for a living resource. In the case of the scallop, which is a plankton feeder, no apparent problem exists as plankton is not harvested in Tasmania. For a scallop management regime to be successfully implemented, there should be a calculation of the MSY for each species/race being fished. This would lead to much effort and expense for the fisheries authorities and also to frustration for fishermen who would have to sort, count and itemise their catch.

For most species of fish, the critical age for harvesting is close to the first age of maturity when growth in weight is rapid and natural mortality is low. Scallops are no exception to this general rule (Gwyther et al. 1984). Thus the reproductive portion of an exploited population would normally be made up of young adults. In the event of a natural catastrophe (such as unseasonally warm or cold water) which killed most fish, the ability of the population to recover is impaired by the lack of mature fish. As scallops are known to have dramatic fluctuations in their annual numbers an MSY prediction could only be made at best on a year to year basis and the dangers associated with an overestimation would be acute.

Although MSY contains these inadequacies it would be unwise to discard the concept entirely. If there is a demand from society for the utilization and conservation of a resource then MSY would appear to form the upper limit of exploitation which would ensure the survival of the species against excessive fishing mortality. This all makes sense in a strictly biological framework, but fisheries managers must contend with more than just biological factors. In particular they must also consider the welfare of the industry participants. Other management concepts have been embraced in recent times which have resulted in a shift from management along strictly biological lines towards the economic management of fisheries. Hence the development of Maximum Economic Yield, a concept which modifies the biologists' MSY model to derive a cost/ revenue curve by transposing yield to its revenue equivalent. By highlighting the low return for effort involved at the margins of MSY, MEY tends - in theory - to establish exploitation levels at a lower total fishing effort than MSY, and might therefore be expected to provide greater protection of the resource from the dangers of overfishing.

Again, however, there are problems which limit its practical applicability. The first problem, and one which is particularly relevant to the Tasmanian scallop fishery, arises from the competing interests of commercial and recreational fishermen. Commercial fishermen usually wish to exploit a resource to maximize their profits while recreational fisherman normally attempt to maximize their pleasure, of which only a portion may be financial return. The commercial fishermen's aims are not contradicted by the concept of MEY when their combined total effort can be controlled; but pleasure for recreational fishermen may mean such intangibles as the escape from suburbanism, aesthetic value of fishing, or hunting instinct release, which will not translate into a computation of MEY. This quandary faces the fisheries managers in the Tasmanian scallop fishery, and an MEY concept in this context would have little value in helping to formulate a joint recreational/commercial fishery management plan.

The second problem with managing a fishery along MEY lines stems from the common property nature of the fishing resource, to be discussed below. Fishermen, like other businessmen, seek to maximize their profits. In a situation where there are no external controls on the number of boats, capital will pour into the industry while fishermen perceive the chance of profits until the profit margin finally dissipates. The late entrants into a fishery will sink capital which, because of reduced stocks and increased total fishing effort, will result in the fishery becoming over-capitalised. Thus in an unregulated fishery the MEY inevitably will be 
surpassed, leading to a need for external intervention to reduce fishing effort. In the Bass Strait scallop fishery there has been a limit on the number of licences issued to fish for scallops, though catch quotas appear to be the favoured option for the fishery's long-term management (B. Lilburn, Chairman, Bass Strait Scallop Fishery Task Force, pers. comm.). This restriction of effort, while having the admirable aim of protecting the resource and increasing profits for participants, is plagued by distributional inequities. The problem of who should get a licence, for instance, is a most vexing one, and fraught with political and ethical problems.

Thirdly, MEY can only be accurately plotted if the price remains constant. But the price of Tasmanian scallops varies within the State and in other States, depending on demand and supply at different times of the year and on the variable costs associated with the different markets to which they are sent. The assumption that fishing vessels, their catch effectiveness and their operating costs are roughly comparable is also invalid, for fishing is undertaken by a variety of sizes of boats with varying operating costs and catch effectiveness. In addition, as with MSY the data base required to make an assessment of MEY for the Tasmanian scallop fishery would be extremely difficult to obtain, due, again, to the reluctance of some fisherman to divulge the information, the need to update constantly cost and price data, and the costs of gathering and processing the information. An accurate assessment of MEY is thus unlikely.

Finally the effects of improvements in fishing technology on the level of effort and economic efficiency further upset any attempts to manage a fishery in accordance with MEY. In a situation where technological improvements are unregulated, fishing effort can rapidly escalate beyond the MEY; however, where they are regulated, account must be made of the economic inefficiencies created by such a policy and the associated problems (Whit marsh 1983). In the scallop fishery there have been a number of technological innovations such as changes in dredge size and efficiency, improvements in boat performance, and the recent introduction of scallop sorting machines to reduce handling time for fishermen. This last innovation has been examined carefully by the Bass Strait Scallop Fishery Task Force to assess its likely affect on scallop numbers. If it is too efficient, that is, if it creates the potential for rapid increases in fishing effort, its use will be restricted - an apposite example of regulated economic inefficiency which prevents a true MEY being taken.

With all these problems is there any value in attempting to manage a fishery on the basis of MEY? It would seem to be inappropriate for the Tasmanian scallop fishery in light of the above. However the MEY model does allow administrators to point out the dangers of excess effort and the importance of the problems posed by common property rights.

A third management paradigm is Optimum Sustainable Yield, a concept which arose from the 1958 Oceans Convention in Geneva (Stroud 1975). Unlike MSY and MEY it provides no models with which to structure practical data theoretically, and its flexibility has led to much criticism (Harville 1975). Who, for instance, is to define "optimum"? Croker (1975) argued that inevitably persons with the most political clout will be the final arbiters of what is optimal. Nor is there agreement about what OSY precisely is; it is usually defined vaguely in terms of MSY or MEY, with some social impact considerations like employment effects or regional social hardships tacked on. At the Australian Fisheries Conference held in Canberra in 1984 three issues were identified in the development of fisheries management plans. These were conservation of resources, economics of the industry and the social implications of any initiatives. If these three criteria are considered as the basis of an OSY programme, the OSY for scallop fisheries managers might be the fishing effort at which yield is below scallop recruitment level while still safely allowing a limited season for fishermen to work. In the latter requirement determination of the 'limited season' is obviously crucial. If the season is too long the problems outlined in the MSY and MEY sections will be encountered. If it is too short fisheries managers will be exposed to criticism for 'locking up' the resource. If restrictions were placed on the number of fishermen entering the fishery then some control on the fishing effort would be possible; however this will inevitably result in distributional inequities, as noted above. In addition, most commercial fishermen would probably interpret the OSY as being somewhat higher than the authority's interpretation, due to their capital outlay and desire to maximise their return on effort. OSY variables for recreational fishermen will differ again, for as we have seen, "unquantifiables' such as the quality of derived pleasure are significant in their case.

It would thus seem that OSY is of limited applicability for the Tasmanian scallop fishery. In a wider sense OSY does attempt to fill the gaps left by the failure of MSY and MEY to address such problems as the sociological effects of management plans on, for example, employment and regional 
hardships, but it clearly requires much greater refinement before it can be considered as an appropriate theoretical construct for the shaping of regulatory practice.

\section{Common Property Rights}

A number of other problems are endemic to management of the scallop ind ustry. The constitutional and political difficulties involved in Bass Strait will not be easily solved and may periodically recur. Problems of technological advance are not only relevant to attempts to evaluate MEY: whatever management strategies are adopted the potential for innovation to inflict consequential damage upon the ind ustry will remain a problem. There are also problems of political will. There will always be a tendency on the part of fishermen to maximize income in the short term and trust the long-term to look after itself (Berkes 1985). This will bring them into conflict with government and management, and in neither case can we assume that the will to resist fishermen's demands will necessarily exist. Politicians are susceptible to pressure from organized, articulate private interests. Administrators have a tendency to avoid the stress associated with an adversarial management relationship with clients by taking on the world view of those clients; a process known as 'clientism', whereby the steward of the public interest ceases to be such, and becomes instead the public sector facilitator of private interests.

How can we account for this divergence between public and private interest? The answer lies in the common property nature of many resources, including scallops. Here, too, much has already been written (Gordon 1954, Crutchfield \& Pontecorvo 1969, Harrison 1975, Copes 1981, Welch 1983). It has long been recognized that the world's fishery crises stem from "the fact that these fisheries are common property resources to which fishermen generally have easy access. The fisheries are open to all who wish to exploit them and are owned by none" (Munro 1981). They tend to be recklessly used "because there are no private incentives to do otherwise" (Eagles 1984); "since fishermen do not own the fish until they have caught them, no individual fisherman can sensibly decide to refrain from fishing to allow the fish to grow and breed" (Victor 1979). Copes (1981) is even more explicit:

"No one fisherman is personally motivated to conserve the resource, for any fish he would return to the water to grow to larger size will likely end up in the nets of a rival fisherman.
Any expense he would undertake to conserve or enhance the fish stock, or to improve general fishery facilities, will yield him a negligible return. Most of the additions to the catch or improvements in returns that he would cause, will be enjoyed by other fishermen. When no individual is able to recoup an invest ment made in the fish stock, everyone will personally incline to neglect the future of the resource."

One influential observer has categorised this the "tragedy of the commons", to which he sees no technical solution, positing instead a moral solution (Hardin 1968) which has ben attacked in turn as politically fanciful and similarly incapable of constituting a solution(Crowe 1969). Hardin's "tragedy of the commons" has been applied to fishing and fish thus:

"It is an important point of the Hardin paradigm that the decline comes about as the result of rational self-interest. Each new boat that a fisherman adds, brings him a gain of almost 1 .

But as the effecs of over-fishing will be shared by all, his loss will be only a fraction of 1 . Thus as a rational decision-maker, the only sensible course for him is to add another boat." (Berkes 1985)

What is to be done? Many argue that the answer is to find ways of turning common property rights into some form of private right (cf. Welch 1983). In practice, as Harmon (1982) points out, once governments act to limit access to their fishing grounds, explicit or implicit property rights are established. A number of mechanisms for bestowing limited property rights which could protect the resource from over-exploitation exist. These could concentrate on industry outputs, in the form of a transferable quota system, whereby ind ustry participants are allotted catch quotas which can be bought and sold. Tasmanian strategies, as with the rest of the world, have concentrated rather on input strategies. Hence the limited entry policy adopted for the time being at least, in the Bass Strait fishery. Sturgess et al. (1982) argue that any successful management strategy must be a modification of this, for although "relatively blunt", "fishermen have come to accept it and, presumably, base their expectations on it continuing", whereas "radical departures from this scheme, such as an output tax or annual output quotas for indiviourals may be resisted by fishermen". Crutchfield (1980) agrees: "a limited entry program can be phased in so that it minimizes the compulsion that must be exerted to trim the level of fishing to desired levels". There are difficulties however. As Meany (1980) and Sturgess \& Meany (1982) point out, it will have little effect 
unless coupled to restrictions on upgrading the fishing capacity of those granted entry. Possibly even more significant are "the profound social and political decisions" which must be made "in relation to the establishment of a limited entry fishery: to which individuals in the society is the exclusive fishing entitlement to be given?"(Dragun 1981-82). No entirely satisfactory system of allocating licences has been devised, and the further danger exists that, once allocated, the ind ustry becomes a closed shop. At a still more general level it is unlikely, on ideological grounds, that there could be consensus on any extension of property rights beyond that conferred by limited entry. Many would agree with Lowry's (1971) call for an affirmation that the world's bodies of water and the resources within them, are inalienable public property.

Finally it has been suggested by Berkes (1985) that traditionally community-based constraints have successfully prevented over-fishing by utilizing a combination of territorial use rights and community moral sanctions to circumvent the "tragedy of the commons", and that herein lies the management solution to the future. Unfortunately, despite his sunny optimism, Berkes' evidence is curiously at odds with his argument: he notes the impossibility of such solutions in large-scale fisheries and that the impetus of technological change is antithetical to small-scale operations, and that in the market economy "economic relations tend to become free from the social framework" and hence beyond the control of informal community control mechanisms. Regrettably we must conclude that this seems an unpromising solution for the immediate and middle future.

\section{SUMMARY}

The history of Tasmania's scallop industry is one of recurring, unresolved problems, despite the periodic implementation of management initiatives. The factors contributing to this are complex and formidable: they are constitutional, political and bureaucratic, but they have still more to do with the biological and the common property natures of the resource, and with the failure to develop and apply satisfactory theoretical management models. Given that technological advances since the 1950 's have greatly increased the ind ustry's harvesting capacity, the need for effective management has been made much more acute. Political pressures can be expected to intensify as well, as entry into the industry becomes increasingly capital-intensive, and the financial consequences to individual fishermen of not having unrestrained access to the fishery are commensurately greater. Our conclusion is that management problems are likely to continue, largely for reasons which are endemic to the scallop's biology and resource-nature, and we should not unreasonably expect rapid progress towards resolution.

\section{REFERENCES}

BERKES, F., 1985: Fishermen and 'the tragedy of the commons'. Environ. Conserv., 12(3): 199-205.

BEVERTON, R.J.\& HOLT, S.J., 1957: On the dynamics of exploited fish populations. Fish. Invest. Minist. Agric. Fish. Food (G.B.) Ser.II, XIX.

BROWN, R.H., 1960: Scallop fishery of Tasmania. Interim Report of Select Committee of the Legislative Council, with Minutes of Proceedings. Tas. Parl. J. and Pap., 163, Paper 74, Government Printer, Hobart.

BROWN, R.H., 1961: Scallop fishery of Tasmania. Final Report of Select Committee of the Legislative Council, with Minutes of Proceedings. Tas. Parl. J. and Pap., 165, Paper 49, Government Printer, Hobart.

COPES, P., 1981: Rational resource management and institutional constraints: the case of the fishery. In Butlin, J.A. (ed.): ECONOMICS AND RESOURCE POLICY. Longman, London.

CROKER, R.S., 1975: Usefulness of the Optimum Yield Concept. In Roedel, P.M. (ed.): OPTIMUM SUSTAINABLE YIELD AS A CONCEPT IN FISHERIES MANAGEMENT. Spec. Pub. 9, American Fisheries Society, Washington, D.C.

CROWE, B.L., 1969: The tregedy of the commons revisited. Science, 166: 1103-1107.

CRUTCHFIELD, J.A. \& PONTECORVO, G., 1969 THE PACIFIC SALMON FISHERIES: $A$ STUDY OF IRRATIONAL CONSERVA$T I O N$. John Hopkins Press, Baltimore.

CRUTCHFIELD, J.A., 1980: Fisheries management the end of the beginning. Aust.Fish., 39:41-49.

DIX, T.G., 1975: Farming the sea. In Banks, M.R. \& Dix, T.G. (eds): RESOURCES OF THE SEA. Royal Society of Tasmania, Hobart.

DIX, T.G., 1981: Preliminary experiments in commercial scallop (Pecten meridionalis) culture in Tasmania. Tasmanian Fish. Res., 23: 18-24.

DRAGUN, A.K., 1981-82: Economic principles of limited-entry fisheries management. Search, 12: 451-453.

EAGLES, P.F.J., 1984: THE PLANNING AND MANAGEMENT OF ENVIRONMENTALLY SENSITIVEAREAS. Longman, Harlow (UK).

FAIRBRIDGE, W.S., 1952: A population study of the Tasmanian commercial scallop, Notovola meridionalis (Tate) Lamellibranchiata: Pectinidae. Aust. J. mar. Freshwat. Res., 4: 1-40.

FLYNN, T.T., 1916: Royal Commission of Tasmanian Fisheries. Report of the Commissioners. Tas. Parl. J. and Pap., LXXV. Government Printer, Hobart. 
FLYNN, T.T., 1918: Scallop Investigation: Preliminary Report by Professor Flynn. Tas. Parl. J. and Pap., LXXIX, Paper 59. Government Printer, Hobart.

FLYNN, T.T., 1919: Scallop Investigation: Second Progress Report. Tas. Parl. J. and Pap., LXXXI, Appendix, Paper 54. Government Printer, Hobart.

FRY, F.E.J., 1947: Statistics of a lake trout fishery. Biometrics, 5: 27-67.

GORDON, H.S., 1954: The economic theory of a common property resource: the fishery. $J$. Pol Econ., 62: 124-142.

GWYTHER, D., McSHANE, P., SAUSE, B., BURGESS, D. \& FOLEY, S., 1984: The Victorian scallop research program, progress to September 1984. Internal Report Number 82: 1-28. Marine Science Laboratories, Queenscliff (Vic.).

HARDIN, G., I968: The tragedy of the commons. Science, 162: 1243-1248.

HARMON, E.J., 1982: Australian resources politics: definition and application. Paper presented at the 24th Annual Conference of the Australasian Political Studies Association, Perth

HARRISON, A.J., 1965: Tasmanian scallop fishery and its future. Aust. Fish. Newsl., 24(5): 9-13.

HARRISON, A.J., 1975: Fisheries management with particular reference to commercially exploited fish stocks around Tasmania. In Banks, M.R.\& Dix, T.G. (eds): RESOURCES OF THE SEA. Royal Society of Tasmania, Hobart.

HARVILLE, J.P., 1975: Multidisciplinary aspects of Optimum Sustainable Yield. In Roedel, P.M (ed.): OPTIMUM SUSTAINABLE YIELDAS A CONCEPT IN FISHERIES MANAGE$M E N T$. Spec. Publ. 9, American Fisheries Society, Washington, D.C.

HENRY, W., 1861: Government Notice 148. Hobart Town Gazette, June-December, XLVI: 1541.

HORTLE, M., 1983: T.F.D.A. scallop project opens up alternatives. Aust. Fish., 42: 34-37.

INNES, F.M., 1865: Report of the Select Committee appointed to devise means to carry into effect the vote of 500 Pounds for the introduction of Salmon. Tas. House Ass. J., Vol.1. Government Printer, Hobart.

LARKIN, P.A., 1977: An epitaph for the concept of Maximum Sustained Yield. Trans, Am. Fish. Soc., 106: 1-11.

LOWRY, R.P., 1971: Toward a radical view of the ecological crisis. Environ. Aff., 1: 350-359.

MEANY, T.F., 1980: The economist: making sure fisheries management pays off. Aust. Fish., 39: 14-16.

MUNRO, G.R., 1981: The economics of fishing: an introduction. In Butlin, J.A. (ed.): ECONO $M I C S A N D$ RESOURCES POLICY. Longman, London.

OGlLVIE, A.G., 1925: Appointment of salmon and freshwater commissioners. Tasm. Gov. Gaz., CXLV. Government Printer, Hobart.
OLSEN, A.M., 1955: Underwater studies on the Tasmanian commercial scallop, Notovola meridionalis (Tate) Lamellibranchia ta: Pectinidae. Aust. J. mar. Freshwat. Res., 6: 392-409.

PRINCE, G.W., McFIE, M.J.\& REID, S., 1960: Scallop fishery of Tasmania. Submissions to the Select Committee of the Legisla tive Council appointed to enquire into the scallop fishery of Tasmania. Clerk of Committees, Legislative Council, Hobart.

RICKER, W.E., 1948: METHODS OF ESTIMATING VITAL STATISTICS OF FISH POPULA$T I O N S$. Indiana University Publications, Science Series 15, Bloomington, Ind.

RICKER, W.E., 1958: HANDBOOK OF COMPUTATIONS FOR BIOLOGICAL STATISTICS OF FISH POPULATIONS. Bulletin 119, Fisheries Research Board of Canada, Ottawa.

RICKER, W.E., 1973: Two mechanisms that make it impossible to maintain peak-period yields from stocks of Pacific salmon and other fishes. $J$. Fish. Res. Bd Can., 30: 1275-1286.

ST LEGER, L.A., 1964: The Tasmanian scallop industry. Tasm. J. Agric., 15: 97-99.

SANDERS, M.J., 1970: Rise and fall of scallop industries. Aust. Fish., 29: 2-11.

SAVILLE-KENT, W., 1886: Superintendent and Inspect or of Fisheries Report for 1885. Tasm. Parl. J. and Pap., VIII, Paper 31 . Government Printer, Hobart.

SCHAEFER, M.B., 1954: Some aspects of the dynamics of populations important to the management of the commercial marine fisheries. Inter-Am. Trop. Tuna Comm. Bull, 1: 27-56.

SEAGER, P.S., 1908: Commissioners of Fisheries Report for 1907-8. Tasm. Parl. J. and Pap., LIX Paper 53. Government Printer, Hobart

SEAGER, P.S., 1910: Commissioners of Fisheries Report for 1909-10. Tasm. Parl. J. and Pap., LXIII, Paper 53. Government Printer, Hobart.

SEAGER, P.S., 1912: Commissioners of Fisheries Report for thee Year 1911-12. Tasm. Parl. J and Pap., LXVII, Paper 49. Government Printer, Hobart.

SEAGER, P.S., 1919: Commissioners of Fisheries Report for the Year 1918-19. Tasm. Parl. J. and Pap., LXXXI, Appendix, paper 54. Government Printer, Hobart.

SEAL, M., ALLPORT C., JOHNSTON, R.M. RIDDOCH, A., SWAN, J., WEBSTER, A.G. BELSTEAD, C.T.\& SWAN, E.D., I883: Royal Commission on the Fisheries of Tasmania, Report of the Commissioner. Tasm. Parl. J. and Pap., House Ass. J., XLIII. Government Printer, Hobart

SHOOBRIDGE, P.G., 1979: First Annual Report of the Fisheries Development Authority, for the year ending 30 June 1978. Tasm. Parl. J. and Pap., Part 1, 201. Government Printer, Hobart.

SMITH, H.C., 1942: Department of Agriculture Annual Report for 1941-1942. Tasm. Parl. J. and Pap., 
CXXVII, Paper 18. Government Printer, Hobart.

STROUD, R.H., 1975: Introductory remarks. In Roedel, P.M. (ed.): OPTIMUM SUSTAINABLE YIELD AS A CONCEPT IN FISHERIES MANAGEMENT. Spec. Publ. 9, American Fisheries Society, Washington, D.C.

STURGESS, N.H., DOW, N. \& BELIN, P., 1982: Management of the Victorian scallop fisheries: retrospect and prospect. In Sturgess, N.H. \& Meany, T.F. (eds): POLICY AND PRACTICE IN FISHERIES MANAGEMENT. Australian Government Publishing Service, Canberra.

STURGESS, N.H. \& MEANY, T.F., 1982: POLICY AND PRACTICE IN FIS HERIES MANAGE$M E N T$. Australian Government Publishing Service, Canberra.
TALBOT L M 1978: WHALES AND WHALING. Report of the Independent Inquiry conducted by the Hon. Sir Sydney Frost. Australian Government Publishing Service, Canberra.

VICTOR, P.A., 1979: Economics and the challenge of environmental issues. In Leiss, W. (ed.): ECOLOGY VERSUS POLITICS IN CANADA. University of Toronto Press, Toronto.

WELCH, W.P., 1983: The political feasibility of full ownership property rights: the cases of pollution and fisheries. Policy Sci., 16: 165-180.

WHITMARSH, D., 1983: Technology, economics and fisheries management. Aust. Fish., 42(12): 45-47.

ZACHARIN, W., 1985: D'Entrecasteaux Channel scallop survey 1985. Unpublished report, Dept Sea Fisheries, Taroona, Tasm.

(accepted I5 August 1986) 